\title{
Mitral Valve Repair for Mitral Valve Regurgitation with Papillary Muscle Displacement and Posterior Leaflet Prolapse
}

\author{
Masaho Okada, Hirotaka Watanuki, Kayo Sugiyama, Yasuhiro Futamura, Katsuhiko Matsuyama \\ Department of Cardiac Surgery, School of Medicine, Aichi Medical University, Nagakute, Japan \\ Email: okmasaho123@gmail.com
}

How to cite this paper: Okada, M., Watanuki, H., Sugiyama, K., Futamura, Y. and Matsuyama, K. (2017) Mitral Valve Repair for Mitral Valve Regurgitation with Papillary Muscle Displacement and Posterior Leaflet Prolapse. Open Journal of Thoracic Surgery, 7, 39-45.

https://doi.org/10.4236/ojts.2017.73006

Received: June 28, 2017

Accepted: August 7, 2017

Published: August 10, 2017

Copyright $\odot 2017$ by authors and Scientific Research Publishing Inc. This work is licensed under the Creative Commons Attribution International License (CC BY 4.0).

http://creativecommons.org/licenses/by/4.0/

cc) (i) Open Access

\begin{abstract}
A case of abnormal chordae of the mitral valve (MV) associated with systolic anterior motion (SAM) is not commonly encountered in clinical practice. Here we report MV repair via the edge-to-edge technique in a 56-year-old male with MV regurgitation associated with papillary muscle displacement and posterior leaflet prolapse. Echocardiography revealed obstruction of the left ventricular outflow tract caused by SAM because of papillary muscle displacement and mitral regurgitation associated with posterior leaflet prolapse due to chordae rupture. MV repair was successfully performed by reconstruction with an Alfieri stitch. The outcome of this case demonstrated that this surgical technique is preferable for MV abnormalities with no complex malformations.
\end{abstract}

\section{Keywords}

Mitral Valve Repair, Systolic Anterior Motion, Papillary Muscle

Displacement, Left Ventricular Outflow Tract Obstruction, Alfieri Stitch

\section{Introduction}

Mitral regurgitation (MR) associated with the abnormal subvalvular apparatus could cause from prolapse or tethering and inflexibility of leaflet. Although the standard mitral valve (MV) techniques, including leaflet resection, chordal replacement, sliding plasty and ring annuloplasty, are widely used, systolic anterior motion (SAM) can still occur after repair. Left ventricular outflow tract obstruction (LVOTO) caused by SAM can occur with hypertrophic obstructive cardiomyopathy (HOCM), complicated by an abnormal mitral valve (MV) and subvalvular apparatus or newly caused with a particular pathophysiology after 
MV repair. The edge to edge technique has been proposed to prevent SAM [1]. Here we report a surgical case of MV prolapse and SAM with papillary muscle displacement.

\section{Case}

A 56-year old male with a history of hypertension developed chest discomfort during exercise. The blood biochemical findings showed a little elevated value for AST, ALT, and BNP (Table 1). The electrocardiogram showed left ventricular hypertrophy with normal sinus rhythm (Figure 1). Echocardiography revealed LVOTO due to papillary muscle displacement, mild septal hypertrophy, and mild MR associated with posterior leaflet prolapse due to chordae rupture (Figure 2). The ejection fraction was 59\% and the septal diameter was $14 \mathrm{~mm}$, indicating mild hypertrophy of LV. The results of the dobutamine stress test estimated that the pressure gradient of LVOT was greater than $150 \mathrm{mmHg}$. At first, cibenzoline was administered for improvement of LVOTO. One month later, a repeated echocardiography showed improved LVOTO, but MR progressed because of posterior leaflet prolapse with no improvement in symptoms.

Table 1. The blood biochemical findings showed a little elevated value for AST, ALT, and BNP.

\begin{tabular}{|c|c|c|}
\hline \multicolumn{3}{|c|}{ Blood biochemical findings } \\
\hline $\mathrm{RBC}$ & 5.17 & $\times 10^{6} / \mu \mathrm{L}$ \\
\hline Haemoglobin & 15.9 & $\mathrm{~g} / \mathrm{dL}$ \\
\hline Haematocrit & 48.0 & $\%$ \\
\hline White blood cells & 7.3 & $\times 10^{3} / \mu \mathrm{L}$ \\
\hline Platelet & 221 & $\times 10^{3} / \mu \mathrm{L}$ \\
\hline Total protein & 6.9 & $\mathrm{~g} / \mathrm{dL}$ \\
\hline Albumin & 4.1 & $\mathrm{~g} / \mathrm{dL}$ \\
\hline Bilirubin & 1.1 & $\mathrm{mg} / \mathrm{dL}$ \\
\hline AST & 62 & $\mathrm{U} / \mathrm{L}$ \\
\hline ALT & 85 & $\mathrm{U} / \mathrm{L}$ \\
\hline LDH & 124 & $\mathrm{mg} / \mathrm{dL}$ \\
\hline Creatine kinase & 98 & $\mathrm{U} / \mathrm{L}$ \\
\hline Potassium & 142 & $\mathrm{mmol} / \mathrm{L}$ \\
\hline Sodium & 4.1 & $\mathrm{mmol} / \mathrm{L}$ \\
\hline Chloride & 108 & $\mathrm{mmol} / \mathrm{L}$ \\
\hline Blood urea nitrogen & 13.6 & $\mathrm{mg} / \mathrm{dL}$ \\
\hline Creatinine & 0.88 & $\mathrm{mg} / \mathrm{dL}$ \\
\hline $\mathrm{BNP}$ & 52.8 & $\mathrm{pg} / \mathrm{dL}$ \\
\hline Glucose & 65 & $\mathrm{mg} / \mathrm{dL}$ \\
\hline Creative protein & 0.16 & $\mathrm{mg} / \mathrm{dL}$ \\
\hline
\end{tabular}




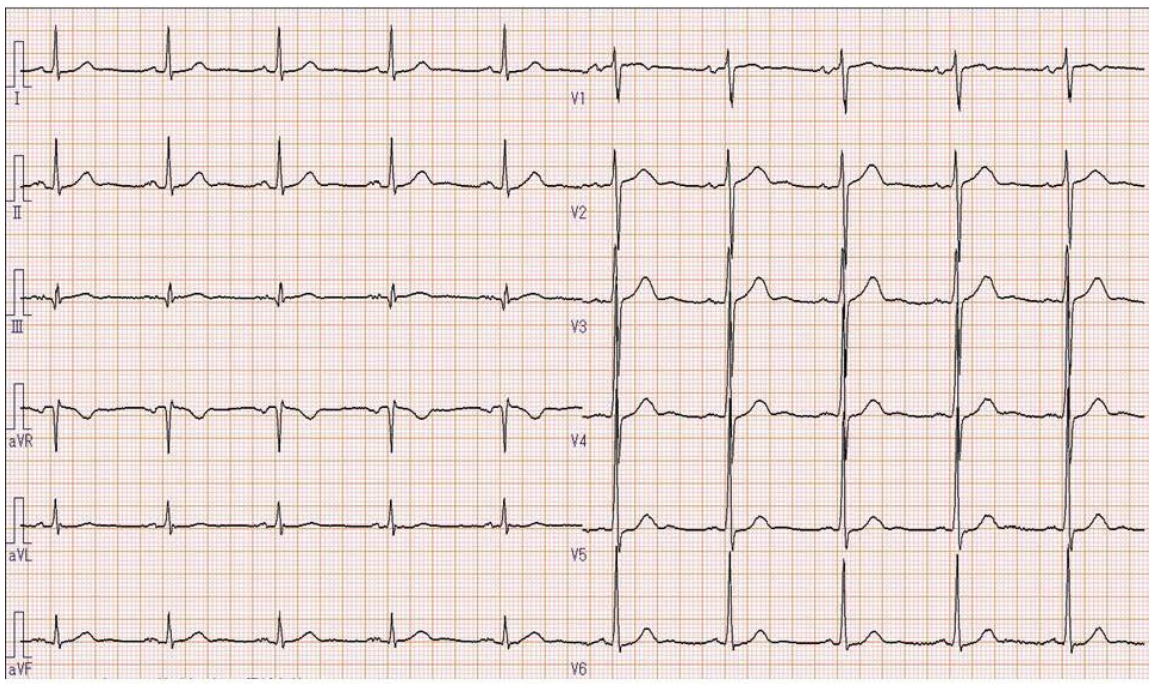

Figure 1. Preoperative electrocardiogram showed left ventricular hypertrophy with normal sinus rhythm.

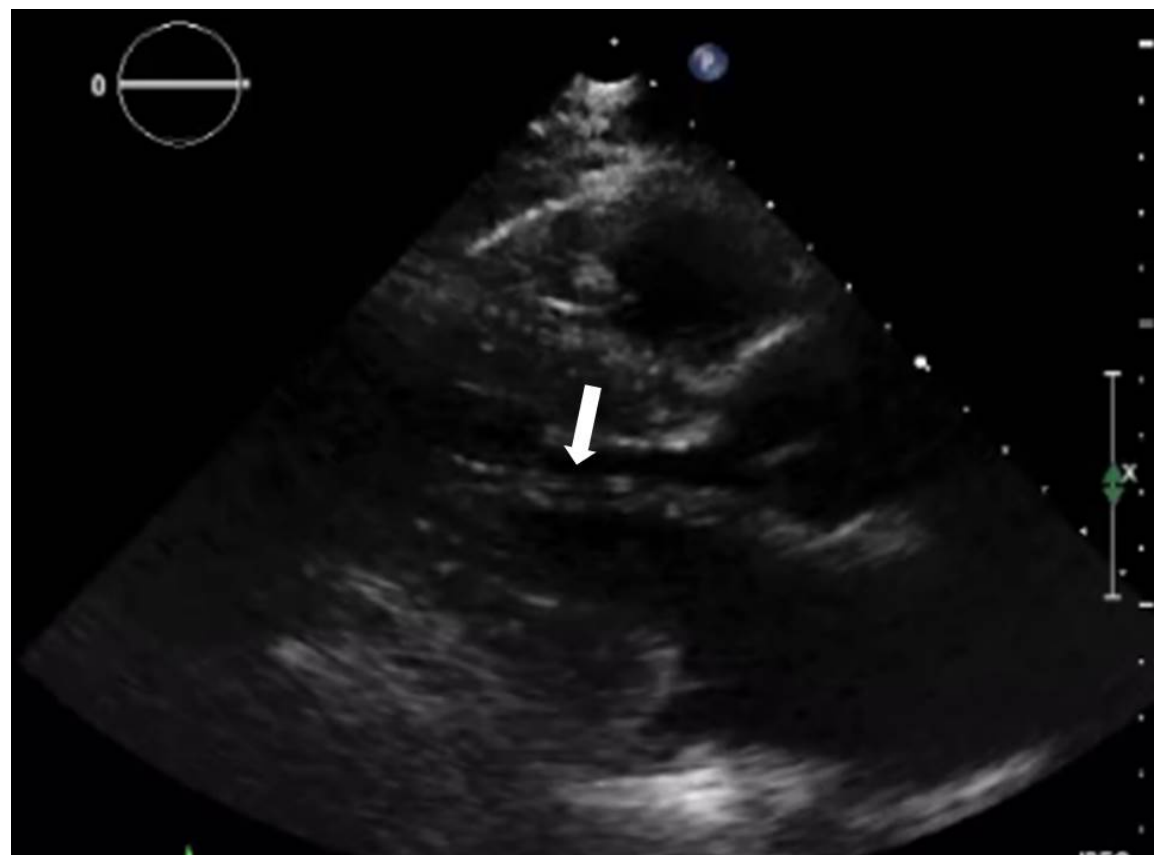

Figure 2. An echocardiography demonstrated restricted chordae of the anomalous papillary muscle (arrow), which resulted in LVOTO.

\section{Surgery and Postoperative Course}

MV was observed through a right-sided atriotomy. The posterior leaflet was prolapsed at P2 because of chordal rupture, and the anterior leaflet was restricted to LV by three bold marginal chordae, which were assumed to be the anomalous papillary muscle (Figure 3). These chordae were cut at the tip of the valve, which increased mobility of the anterior leaflet. An Alfieri stitch was placed between A2 and P2 using 5 - 0 prolene, and an artificial chorda was reconstructed at A3 (Figure 4). Mitral annuloplasty was then performed using 


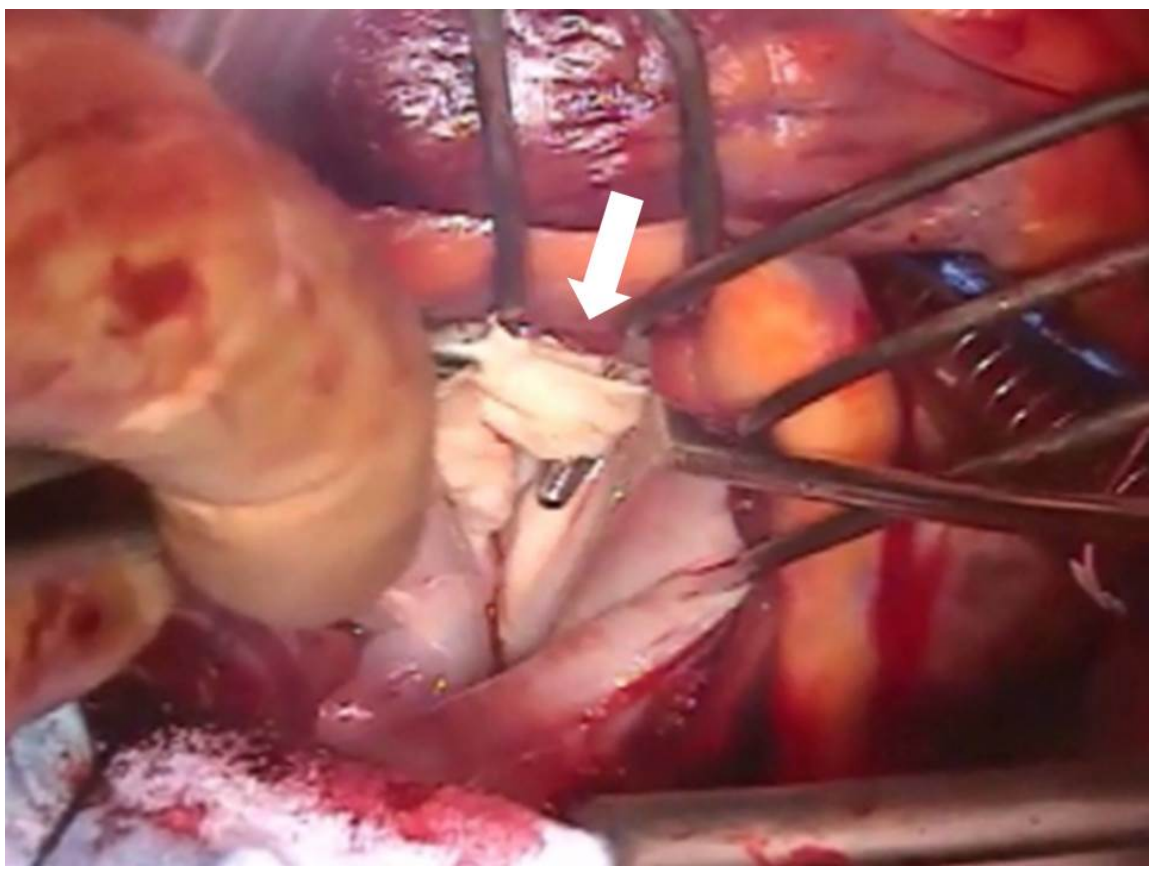

Figure 3. Intra-operative findings of anomalies of mitral subvalvular apparatus. The anterior leaflet was restricted to LV by bold marginal chordae (indicated by allow).

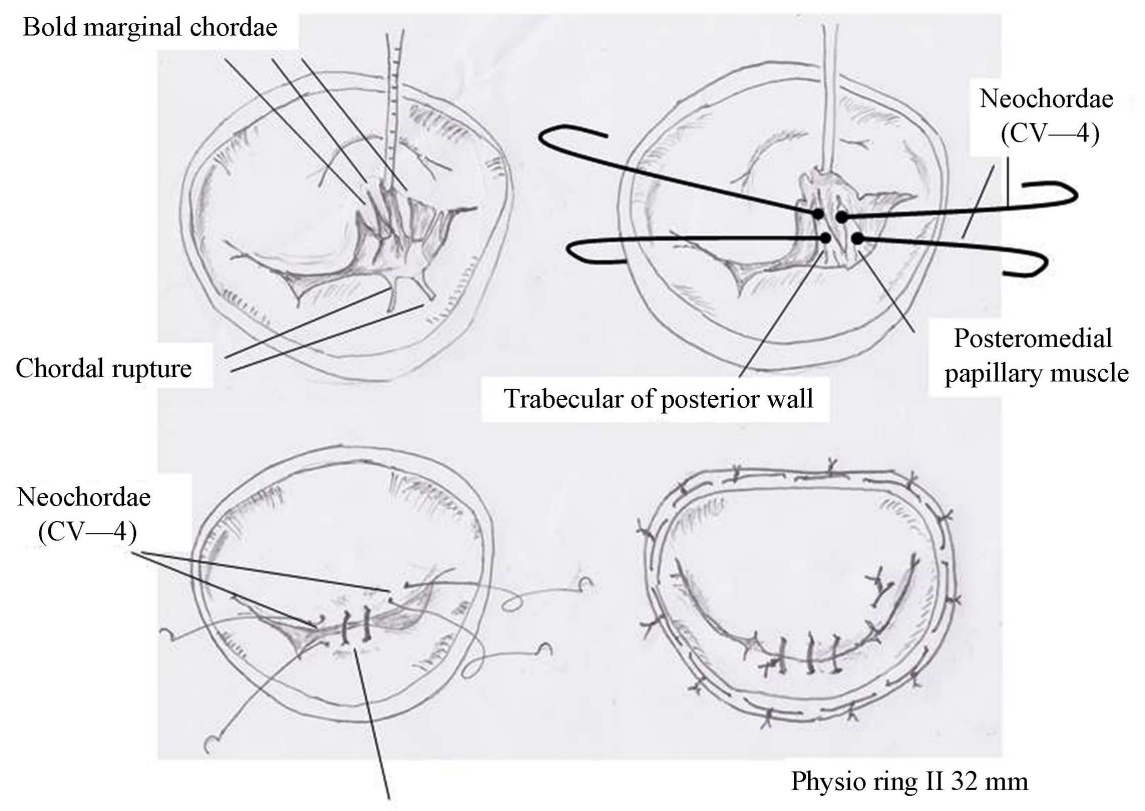

Edge to edge stitch

Figure 4. Shematic view of this surgery. The posterior leaflet was prolapsed at P2 because of chordal rupture, and the anterior leaflet was restricted to LV by bold marginal chordae. An Alfieri stitch was placed and an artificial chordae was reconstructed. Mitral annuloplasty was then performed using a 32-mm Carpentier-Edwards Physio II ring.

a 32-mm Carpentier-Edwards Physio II ring (Edwards Lifesciences, Irvine, CA, USA). The diameters of the anterolateral and posteromedial orifices were measured using 22-mm and 18-mm Hegar dilators, respectively. The water test re- 
vealed the disappearance of MR. Postoperative echocardiography showed trivial MR without SAM and the effective MV area was $2.2 \mathrm{~cm}^{2}$ (Figure 5). The patient was discharged on postoperative day 16.

\section{Discussion}

Cibenzoline, a class IA antiarrhythmic agent, has been reported to have beneficial effects on the left ventricular pressure gradient (LVPG) and diastolic function [2]. Chronic use of cibenzoline is reported to attenuate LVPG, improve LV diastolic dysfunction, and induce regression of LV hypertrophy in patients with HOCM [3]. In this case, cibenzoline was an effective treatment for LVOTO.

The phenotypic manifestations of hypertrophic cardiomyopathy (HCM) include abnormalities of the MV and subvalvular apparatus that may be responsible for outflow obstruction [4]. Insertion of the anomalous papillary muscle into the anterior mitral leaflet represents a mechanism of obstruction to the left ventricular outflow in patients with HCM [5]. Matsumaru et al. reported MV repair for undifferentiated papillary muscle caused by prolapse or tethering and impaired flexibility of the leaflets [6]. The central double orifice technique is reportedly both effective and durable [1]. The most common indications for the edge-to-edge technique are bileaflet prolapse, segmental anterior leaflet prolapse, commissural prolapse, and functional MR. The findings of a previous study demonstrated that a combination of myectomy and Alfieri modification prevented the need for mitral valve replacement and relieved both LVOTO and the patient's symptoms [7]. This technique is used to unite the two leaflets over a short length to prevent their displacement into the outflow tract, thereby

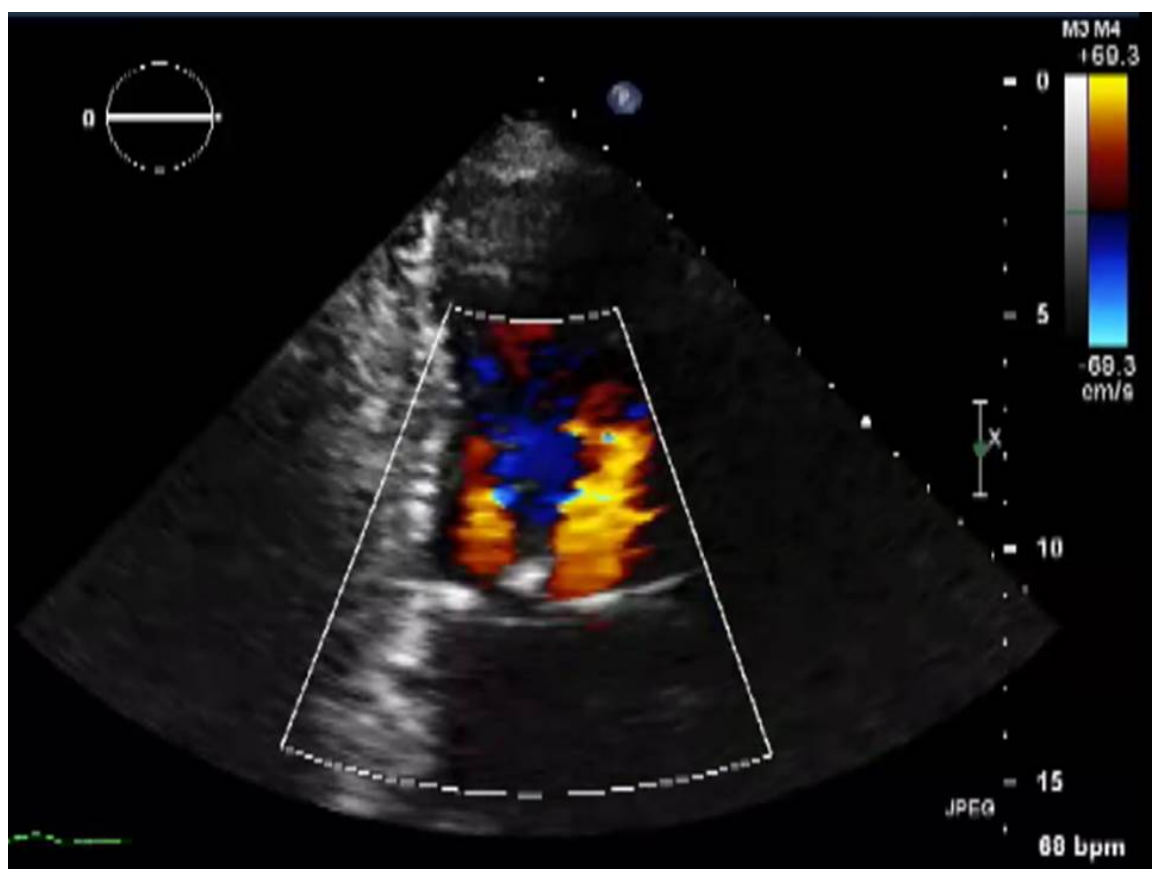

Figure 5. A postoperative echocardiography showed double orifice flow to the LV without significant mitral stenosis. 
blocking the cascade of events leading to SAM after LVOTO [8]. The edge-toedge technique assists rapid and effective treatment of SAM and can be beneficial in such challenging clinical situations [9].

There were some other options for MV repair in this case. Although choral replacement in the posterior leaflet in combination with annuloplasty is the standard option, there remains the risk of SAM without septal myectomy. In this case, the myectomy was not performed, because this case did not meet the critical criterion for HOCM on the basis of the pathophysiology and the septal wall thickness was not so severe as to require myectomy, carrying the risk of septal perforation. Another option is augmentation of the anterior leaflet for the restricted chordae in combination with reconstruction of the artificial chorda of the posterior leaflet with annuloplasty. However, this option is technically complicated. Finally, valve replacement with prosthesis is also a conventional procedure for this pathophysiology. In this case, however, valve replacement was avoided because of the patient's age.

In the current case, an abnormal chorda was associated with SAM. The abnormal chorda was cut and the MV was repaired with an Alfieri stitch. This reconstruction method of the MV leads to prevention of SAM and control of MR. The echocardiography including the flexibility of repaired mitral valve and LV function should be followed overtime.

\section{Conflicts of Interest}

None of the authors have any conflicts of interest associated with this study.

\section{References}

[1] Alfieri, O, Maisano, F, De Bonis, M, Stefano, PL, Torracca, L, Oppizzi, M. and La Canna, G. (2001) The Double-Orifice Technique in Mitral Valve Repair: A Simple Solution for Complex Problems. The Journal of Thoracic and Cardiovascular Surgery, 122, 674-681. https://doi.org/10.1067/mtc.2001.117277

[2] Kondo, I., Mizushige, K., Nozaki, S., Iwado, Y., Masugata, H., Kohno, M. and Matsuo, H. (2001) Effect of Cibenzoline, a Class Ia Antiarrhythmic Agent, on Left Ventricular Diastolic Function in Hypertrophic Cardiomyopathy. Cardiovascular Drugs and Therapy, 15, 459-465. https://doi.org/10.1023/A:1013366211927

[3] Hamada, M., Ikeda, S., Ohshima, K., Nakamura, M., Kubota, N., Ogimoto, A. and Shigematsu, Y. (2016) Impact of Chronic Use of Cibenzoline on Left Ventricular Pressure Gradient and Left Ventricular Remodeling in Patients with Hypertrophic Obstructive Cardiomyopathy. Journal of Cardiology, 67, 279-286. https://doi.org/10.1016/j.jjcc.2015.05.014

[4] Maron, B.J., Nishimura, R.A. and Danielson, G.K. (1998) Pitfalls in Clinical Recognition and a Novel Operative Approach for Hypertrophic Cardiomyopathy with Severe Outflow Obstruction Due to Anomalous Papillary Muscle. Circulation, 98, 2505-2508. https://doi.org/10.1161/01.CIR.98.23.2505

[5] Klues, H.G., Roberts, W.C. and Maron, B.J. (1991) Anomalous Insertion of Papillary Muscle Directly into Anterior Mitral Leaflet in Hypertrophic Cardiomyopathy. Significance in Producing Left Ventricular Outflow Obstruction. Circulation, 84, 1188-1197. https://doi.org/10.1161/01.CIR.84.3.1188 
[6] Matsumaru, I., Hashizume, K., Ariyoshi, T., Izumi, K., Onohara, D., Nakaji, S., Sumi, M., Eishi, K., Tsuneto, A. and Hayashi, T. (2012) Characteristics and Treatment Strategies of Mitral Regurgitation Associated with Undifferentiated Papillary Muscle. Gen Thorac Cardiovasc Surg, 60, 406-410. https://doi.org/10.1007/s11748-012-0055-x

[7] Sado, D.M., Flett, A.S., McGregor, C.G., Pantazis, A.A., Elliott, P.M. and Moon, J.C. (2010) Myectomy plus Alfieri Technique for Outflow Tract Obstruction in Hypertrophic Cardiomyopathy. Circulation, 122, 938-939. https://doi.org/10.1161/CIRCULATIONAHA.110.969451

[8] Mascagni, R., Al Attar, N., Lamarra, M., Calvi, S., Tripodi, A., Mebazaa, A. and Lessana, A. (2005) Edge-to-Edge Technique to Treat Post-Mitral Valve Repair Systolic Anterior Motion and Left Ventricular Outflow Tract Obstruction. The Annals of Thoracic Surgery, 79, 471-473; Discussion 4. https://doi.org/10.1016/j.athoracsur.2004.08.008

[9] Gillinov, A.M., Smedira, N.G. and Shiota, T. (2004) Use of the Alfieri Edge-to-Edge Technique to Eliminate Left Ventricular Outflow Tract Obstruction Caused by Mitral Systolic Anterior Motion. The Annals of Thoracic Surgery, 78, e92-e93. https://doi.org/10.1016/j.athoracsur.2004.03.089

\section{Submit or recommend next manuscript to SCIRP and we will provide best} service for you:

Accepting pre-submission inquiries through Email, Facebook, LinkedIn, Twitter, etc. A wide selection of journals (inclusive of 9 subjects, more than 200 journals)

Providing 24-hour high-quality service

User-friendly online submission system

Fair and swift peer-review system

Efficient typesetting and proofreading procedure

Display of the result of downloads and visits, as well as the number of cited articles

Maximum dissemination of your research work

Submit your manuscript at: http://papersubmission.scirp.org/

Or contact ojts@scirp.org 